\title{
ZAKAT SAHAM DAN OBLIGASI: HARUSKAH?
}

\author{
${ }^{1}$ Ani Sofia Diyani, ${ }^{2}$ Karlina \\ 1,2IAIN Syekh Nurjati, Indonesia \\ Email: 1anisofie24@gmail.com, 2karlinacempaka@gmail.com
}

\begin{abstract}
This Reserch analyzes about Yusuf Qardhawi's view regarding zakat on shares. Besides analyzing also zakat bonds. This is a contradiction between scientists at that time because the law was still not clearly stated or in the Qur'an or hadith. The method used to analyze both of them uses descriptive method by reviewing published journals and other written works as a reference to get a conclusion. The short comings of this journal are investigated by not including the original sources contained in the book written directly by Yusuf Qardhawi and the lack of references obtained to find conclusions that are appropriate and the lack of implementation in term of the public. The conclusion resulting from this analysis is that every zahr and bonds owned by shareholders are obliged to be zakat. Nishab and haul on shares obtained are equated with gold zakat zakah on shares and bonds, which is two and a half percent of the yield or on the nisab which is eighty-five gramsof gold with a haul for one year.
\end{abstract}

Keyword: Zakat, Stock, Bond.

\begin{abstract}
ABSTRAK
Penelitian ini mennganalisis tentang pandangan Yusuf Qardhawi mengenai zakat saham. Selain itu menganalisis juga zakat obligasi. Hal ini menjadi pertentangan antara pada ilmuan pada zaman tersebut karena hukumnya masih belum tercantumkan secara jelas ataupun dalam al-quran ataupun hadist. Adapun metode yang digunakan untuk menganalisis keduanya dengan menggunakan metode deskriptif dengan mengkaji dari jurnal-jurnal yang sudah diterbitkan serta karya tulis lainnya sebagai referensi untuk memperoleh suatu kesimpulan. Kekurangan dari jurnal ini diteliti adalah tidak dimasukkannya sumber asli yang terdapat dari kitab yang ditulis langsung oleh Yusuf Qardhawi serta kurangnya referensi yang didapatkan untuk mencari kesimpulan yang sesuai dan belum adanya pengimplementasian dalam halayak masyarakat. Kesimpulan yang dihasilkan dari analisis ini adalah pada setiap zaham dan obligasi yang dimiliki oleh pemilik saham wajib baginya untuk dizakati. Nisab dan haul pada saham yang diperoleh disamakan dengan zakat emas. Zakat saham dan obligasi yaitu dua setengah persen dari hasil atau atas nisab yang dimiliki.yakni delapan puluh lima gram emas dengan haul selama satu tahun.
\end{abstract}

Kata Kunci: Zakat, Saham, Obligasi

\section{PENDAHULUAN}

Kebijakan investasi yang sedang berjalan ada 4 untuk konvensional yaitu, obligasi, saham, valas dan reksadana. Kebijakan yang dilakukan pemerintahan akan adanya investasi ini. Lebih memfokuskan pada saham dan obligasi. Sedangkan dalam islam diatur kebijakan investasi yaitu kebijakan mengenai sukuk dan saham. 
Sukuk atau lebih dikenal dengan obligasi telah dikenalkan dalam peraturan pemerintah dengan diluncurkan dalam PSAK yang menjelaskan sistem perhitungan dan lain sebagainya. Pada saham juga sudah dikenakan sistem syariah yang mana dapat menyaring dari menjadi saham-saham yang sesuai dengan syariat islam yang tentu saja profitnya tidak akan diragukan.

Sukuk dan saham merupakan salah satu yang merupakan kekayaan dapat Bertambah dalam jangka waktu tertentu. Maka dari itu perlu dikenakan zakat. Menurut Badan Amil Zakat Nasional (BAZNAS), Zakat saham ditetapkan berdasarkan kesepakatan para ulama pada Muktamar Internasional Pertama tentang zakat di Kuwait (29 Rajab 1404 H) bahwa hasil dari keuntungan investasi saham wajib dikeluarkan zakanya. Zakat saham dan sukuk juga termasuk didalamnya (Beik, 2019).

Beberapa penelitian yang meneliti mengenai presfektif ysuf qhardhawi mengenai zakat saham dan oligasi ialah riset yang dilakukan Fauziyah (2010) menemukan bahwa saham dan obligasi dikenai kewajiban zakat sebesar 2,5\%, setelah nilai peralatan yang masuk dalam saham dihitung dan untuk bunga dikeluarkan dari aset zakat. Hal ini sama dengan deposito yang wajib dikeluarkan zakatnya dengan tidak memperhitungkan bunganya. Jadi, saham dan obligasi wajib dikeluarkan zakatnya oleh setiap muslim yang telah memenuhi kewajiban zakat.

Fielnanda (2018) menegaskan pula bahwa bagi perusahaan yang menjual hasil industri dan lain sebagianya, maka dipungut zakat dari sahamnya termasuk keuntungan yang diperoleh dengan presentasi zakat sebesar 2,5\% dan bunga yang dimiliki tidak dihitung menjadi bagian aset zakat. Adapun zakat nya dikeluarkan jika memenuhi 87 gram emas sesuai dengan harga yang berlaku dipasar. Namun demikian, riset yang dilakukan. Mubarak (2017) menemukan bahwa banyak dari pemilik saham dan ob ligasi yang belum mengetahui dan memahami tentang kewajiban zakat pada kedua jenis investasi itu, sehingga banyak dari masyarakat belum mengeluarkan zakat.

Banyak riset yang dilakukan oleh peneliti tentang zakat saham dan obligasi. Penelitian tersebut menunjukkan bahwa kedua investasi itu wajib dikeluarkan zakatnya setelah memenuhi syarat. Kewajiban zakat yang dikeluarkan sebesar 2,5\% karena termasuk dalam kategori zakat harta dengan ukuran nisab 87 gram emas, sedangkan bunga yang ada tidak termasuk aset zakat (Fauziah, 2010; Fielnanda, 2018; dan Mubarak, 2017). Zakat saham dan obligasi kemudian dikaji oleh Yusuf Qardhawi yang merupakan tokoh islam kontemporer. Yusuf Qardhawi memberikan pencerahan mengenai peraturan-peraturan baru yang tidak dikategorikan dalam Al-Quran termasuk adanya zakat saham dan obligasi. Namun, pada saat peluncuran zakat saham dan obligasi adanya penolakan dan menimbulkan kontrofersi. Pandangan terhadap zakat saham dan obligasi, karena hal tersebut akan dibahas mengenai 
pandangan Yusuf Qardhawi mengenai zakat saham dan obligasi. Selain itu dipelajari sekilas mengenai perkembangan saham dan sukuk atau obligasi yang dikembangkan menurut syariah serta zakat profesi.

\section{LANDASAN TEORI}

Saham merupakan adanya simbol penyertaan pada perusahaan dalam meningkatkan perusahaan.investor mendapatkan keuntungan dari penanaman modal yaitu dengan keuntungan. Keuntungan yang dapat yaitu dividen, capital gain serta keuntungan non finansial lainnya, seperti kebanggaan dan kekuasaan memperoleh hak suara dalam menentukan jalannya perusahaan (Yulia, 2016).

Perkembangan saham syariah tidak terlepas dari Bursa Efek Indonesia (BEI) Pada tanggal 3 Juli 2000 yang menerterbitkan Jakarta Islamic Index (JII). JII memuat 30 saham yang dapat menjadi rujukan investor syariah dalam melakukan jual beli. Pada tanggal 12 September tahun 2007 diluncurkan Daftar Efek Syariah (DES) atau IndeksSaham Syariah Indonesia (ISSI) oleh Badan Pemeriksa Pasar Modal (Bapepam) dan Lembaga Keuangan (LK). Dalam indeks tersebut terdapat saham yang sudah disaring dengan menggunakan kriteria yang sudah ditentukan oleh PeraturanBapepam dan LK Nomor II.K.1, yang terdapat pembaharuan terhadap peraturannya pada tahun 2009 (Segara, 2019).

Saham yang harus dizakati menurut Fatimah (2018) adalah perusahaan yang mempunyai barang untuk di jual belikan tidak dengan perusahaan berbasis jasa. Contoh dari sahamnya ialah perusahaan dagang internasional, perusahaan export import dan lain lain (Fatimah, 2018). Obligasi secara terminologi hukum belanda disebut dengan istilah "obligatielening", yaitu yang berarti secarik bukti pinjaman uang yang dikeluarkan oleh suatu perseroan atau badan hukum. Dengan demikian, obligasi adalah surat hutang (pada umumnya berjangka panjang) yang diterbitkan oleh suatu perusahaan atau pemerintah. Obligasi juga dapat disebut sebagai surat berharga, karena pemegang obligasi memiliki klaim terhadap pembayaran bunga dan pokok pinjaman yang telah ditetapkan

Menurut pasal 1 butir 34 keputusan Menteri Keuangan Nomor 1548/KMK.- 013/1990 sebagaimana telah diubah dengan keputusan Menteri Keuangan Nomor 1199/KMK. 010/1990: Obligasi adalah bukti utang dari emiten yang mengandung janji pembayaran bunga atau janji lainnya serta pelunasan pokok pinjaman yang dilakukan pada tanggal jatuh tempo, sekurang-kurangnya tiga tahun sejak tanggal emisi. Dengan demikian, maka secara umum obligasi adalah surat tagihan hutang atas beban tanggungan pihak yang menerbitkan atau mengeluarkan obligasi.

Sukuk adalah efek syariah berupa sertifikat atau bukti kepemilikan yang bernilai sama dan mewakili bagianyang tidak tertentu (tidak terpisahkan atau tidak terbagi) atas aset 
berwujud tertentu, manfaat atas aset berwujud tertentu baik yang sudah ada maupun yang akan ada, jasa yang sudah ada maupun yang akan ada, aset proyek tertentu atau kegiatan investasi yang telah ditentukan. (Warsito, 2019) Sukuk merupakan Efek Syariah yang memiliki ciri-ciri bereda dengan obligasi Sukuk bukan merupakan surat utang, namun, sukuk adalah bukti kepemilikan bersama atas suatu aset/proyek. Pada sukuk harus terdapat asset yang mendasari peluncuran sukuk (underlying asset). Klaim kepemilikan pada sukuk didasarkan pada aset/proyek yang spesifik. Penggunaan dana sukuk harus digunakan untuk kegiatan usaha yang halal. Imbalan bagi pemegang sukuk dapat berupa imbalan, bagi hasil, atau marjin, sesuai dengan jenis akad yang digunakan dalam penerbitan sukuk (Segara, 2019).

Obligasi termasuk harta yang wajib dizakati ditinjau dari pengimplementasian dalil yang masih umum dan tidak berlaku khusus, adanya ijma ulama yang menyepakatinya, fungsi analogi yang sesuai terakhir mempertimangkan tujuan dan manfaat yang dihasilkan (Sholeh, 2015). Obligasi tidak diharuskan dizakati ketika ada dalam tangan pemilik selama kurang dari setahun. Harus dizakatinya obligasi ketika sudah mencapai satu tahun atau lebih. Hal ini erdasarkan pendapat sebagian besar ulama yang mengatakan jika piutang yang dipinjamkan kepada orang lain kemungkinan besar kemali maka sudah dianggap adanya kepemilikan dari peminjaman itu.

\section{METODOLOGI}

Metode yang dilakuan ialah deskriptif. Jenis ini menngumpulkan beberapa sumber yang ada kemudian disimpulkan menjadi satu atau kepustakaan. Hal ini akan menjelaskan sekilas tentang kehidupan beliau dan pandangannya mengenai saham serta sukuk atau obligasi. Pengumpulan data dilakukan dengan menggumpulkan jurnal-jurnal dan skripsi yang menjelaskan tentanng saham juga sukuk, selain tu menjelaskan tentang zakat dan cara perhitungan. Kemudian, mengumpulkan data mengenai pandangan Yusuf Qardhawi mengenai zakat saham dan sukuk.

\section{HASIL DAN PEMBAHASAN}

Hasil Pemikiran Yusuf Qardhawi Mengenai Zakat Saham dan Obligasi Salah satu objek zakat yang sampai hari ini masih diperdebatkan ahli hukum Islam, adalah zakat profesi. Ada banyak hal yang menyebabkan zakat profesi secara hukum dianggap tanpa dasar pijakan yang kuat dalam tradisi hukum Islam, diantaranya; keberadaan zakat profesi belum pernah dipraktekkan oleh Nabi SAW pada zaman dia masih hidup hal ini membuat eksistensi zakat profesi ini menjadi hal yang dianggap historis dalam syariat Islam. (Aziz \& Sholikah, 2015) 
Yusuf Qardhawi menetapkan nisab pada zakat profesi sebanding dengan 85 emas atau disanamakan dengan zakat perhiasan. Kadar yang harus dizakatinya seesar 2,5\% (Aziz \& Sholikah, 2015) sementara untuk haulya disamakan dengan zakat perdagangan yaitu satu tahun. Ketentuan mengenai zakat profesi disesuaikan dan disamakan hukumnya dengan zakat pertanian atau petambangan. Takaran nisab dalam perhitungan pertanian yaitu $653 \mathrm{~kg}$. cara pengambilan dilakukan sesuai dengan penghasilan bersih namun ada beberapa sebab yang membuat zakat menjadikan gaji kotor sebagai perhitungan pengamilan zakat antara lain,tidak teratasya keinginan seseorang, mendidik mental pegawai agar mempunyai mental zakat, kecederungan terlihat mewah, mengurangi beban pajak dan lain sebagainya (Salimah et al, 2017). Ditetapkannya zakat profesi yusuf qardhawi kemudian memecah zakat menjadi sembilan salah satunya zakat saham dan obligasi.

Yusuf Qardhawi mengambil ijtihad pada zakat saham juga obligasi dimulai sejak Qardhawi menerbitkan karyanya yaitu Fiqh Al-Zakat dalam 2 jilid. Pemikiran yang mengunci pemikiran zakat secara tradisional, didobrak dengan banyaknya macammacam hal yang baru sehubungan dengan zakat. Salah satu yang baru ialah zakat saham dan zakat obligasi (AlFarisi \& Setyawan, 2015). Pendapat dari Abdul Wahab Khallaf tentang zakat yaitu:

"Penghasilan dan profesi dapat diambil zakatnya bila sudah setahun dan cukup senisab. Jika kita memperhatikan dan berpegang kepada pendapat Abu Hanifah, Abu Yusuf, dan Muhammad (al Syaibani, pent.) bahwa nisab tidak perlu harus 100 Metode Istinbat Hukum Zakat Profesi Perspektif Yusuf Alqardawi tercapai sepanjang tahun, tapi cukup tercapai penuh antara du ujung tahun tanpa kurang di tengah-tengah kita dapat menyimpulkan bahwa dengan penafsiran tersebut memungkinkan untuk mewajibkan zakat atas hasil penghasilan setiap tahun, karena hasil itu jarang terhenti sepanjang tahun bahkan kebanyakan mencapai kedua sisi ujung tahun tersebut. Berdasar hal itu, kita dapat menetapkan hasil penghasilan sebagai sumber zakat, karena terdapatnya illat (penyebab), yang menurut ulama-ulama fikih sah, dan nisab, yang merupakan landasan wajib zakat"

Pendapat ini adalah kesimpulan dari Abdul Wahab Khallaf tentang zakat dan menjadi batu pijakan bagi Yusuf Qardhawi menjelaskan hukun zakat profesi pada zaman modern yusuf qardhawi kemudian menggunakan pndapat terseut untuk menjadi penentu aturan zakat pada zaman modern, dan dalam hal ini adaya pertentangan dari piha-pihak meski hal ini merupakan salah satu solusi untuk mengatasi kemiskinan dimasyarakat (Aziz \& Sholikah, 2015).

Sekelompok ulama Syekh Abdur Rahman Isa berpendapat zakat saham bisa ditetapkan jika saham tersebut dikeluarkan atau dimiliki seseorang dalam industri murni dan tidak dilakukan kegiatan dagang seperti hotel, kendaraan, pabrik,usaha yang mengadakan 
kegiatan dagang. Hal ini mewajibkan adanya pengeluaran zakat untuk perusahaan dagang. bentuk zakatnya terdapat pada keuntungan yang di dapat dari usaha tersebut, sama seperti zakat pertanian ketika terdapat hasil dari pertanian bukan tanah pertaniannya (Fauziyah, 2010). Sedangkan Yusuf Qardhawi lebih mengelompokkan pada perusahaan industri atau tidak. Namun beliau memiliki pendapat yaitu hal yang digunakan seagai perhitungan zakat adalah keutungan bersih (Ridho, 2018).

Menurut Fienlnada (2017) bahwa Yusuf Qardhawi menerbitkan saham memeiliki serta menjualbelikan juga adanya kegiatan bisnis saham adalah halal. Selama saham terseut mendukung perusahaan dan tidak melakukan bisnis yang diharamkan. Sedangkan mengenai obligasi Yusuf Qardhawi berpendapat obligasi merupakan hutang pemerintah kepada pemilik obligasi. Pemilik obligasi ialah yang memilki piutang terhadap perusahaan yang ditangguhkan bayarannya, karenanya adanya zakat pada obligasi ketika uang yang di terima dari obligasi telah mencapai nisabnya yaitu satu tahun. Ketika keuntungan dan biaya obligasi telah diterima namun tidak mencapai satu tahun maka tidak dikenakan zakat. (Fauziyah, 2010) alasan adanya pemungutan zakat setelah cairnya hasil saham atau obligasi dengan hitungan pendapatan dihitung dari total harga setiap tahunnya. (Prastyo, 2019)

Menurut Al-Farisi \& Setyawan (2015) adanya pembagian menjadi 2 penentuan zakat obligasi dan saham antara lain yang berlaku dipasaran yaitu 2,5 persen. Kedua,dipungut dari keuntungan bersih seesar 10 persen. Melengkapi Al-Farisi \& Setyawan (2015), Fauziyah (2010), Ridho (2018), Prastyo (2019). Menerangkan menurut Yusuf Qardhawi yang menggunakan zakat 10 persen ialah perusahaan semi industry yang menjadikan peralatan atau gedung sebagai modal. Perusahaan yang dikenakan zakat seharga 2,5 persen yaitu perusahaan-perusahaan yang memiliki arang yang diperjual belikan untuk mendapatkan keuntungan. Ketika terdapat penjualan di tegah-tengah masa haul dan nisab, maka perll ditambahkan nilai yang sudah terjual dalam perhitungan zakat (Fielnanda, 2017).

Menurut Ridho (2018) Yusuf Qardhawi memberikan pungutan zakat pada setiap perusahaan tanpa mengenal perusahaan tersebut bersifat industri atau bukan. Menurut Rukhoyah (2016) implementasi zakat saham ialah ketika suatu perusahaan memiliki saham sebesar 1000 dinar dan mempunyai keuntungan 200 dinar, maka totalan saham dan keuntungan diamil 2,5 persennya, total saham dan keuntungan 1200 dinar. Jadi total yang harus dikeluarkan perusahaan untuk zakat ialah 2,5 persen yaitu 30 dinar. Yusuf Qardhawi memberikan pertentangan terhadap penyataan Syekh Adul Rahman Isa bahwa obligasi yang belum jatuh tempo tidak belum diharuskan dizakati. Menurut beliau obligasi meski belum diterima pemayarannya, tetapi piutang tersebut termasuk piutang yang dapat diterima nantinya dan dikenakan zakat 2,5 persen (Rukhoyah, 2016). 
Menurut Aziz \& Sholikah (2015) Zakat Saham dan Obligasi Yusuf Qardhawi menggunakan qiyas dalam menentukan hukumnya dengan ketentuannya dianalogikan pada zakat Saham dan Obligasi adalah emas dan perak, illat atau dasar sifat dasar hukumnya berkembang. Namun meski adanya perdeatan melihat dari sisi hukum ulama- ulama sepakat untuk adanya zakat bagi yang memiliki saham dan obligasi. (Fauziyah, 2010)

\section{SIMPULAN}

Yusuf Qardhawi sebagai ilmuan muslim mengkaji banyak buku serta mengeluarkan banyak karya diantaranya mengenai zakat saham dan obligasi. Menurut Yususf Qardhawi zakat saham dan zakat obligasi perlu adanya zakat. Zakat yang dikenakan kepada setiap saham dan obligasi yang sudah mencapai nisabnya sebesar 2,5 pesen namun ada pengecualian terhadap perusahaan yang memiliki saham yang peralatan sebagai alat menghasilkan uang contohnya sewa gedung, dikenakan tarif 10 persen untuk setiap nisabnya. Pada Obligasi terdapat pengecualian jika belum mencapai 1 tahun pada jangka waktunya tidak akan berlaku obligasi yag dimiliki untuk dizakati.

Adapun nisab yang dijadikan patokan sama dengan nisab emas dan perak yaitu 85 gram. Zakat saham dan obligasi juga dikategorikan seagai zakat profesi. Haul yang ditentukan untuk zakat saham dan obligasi ialah 1 tahun. Jika tidak sampai pada batas haul dan nisab, maka tidak dikenakan zakat. Oleh sebab itu adanya keharusan memngrluarkan zakat untuk seseorang yang mempunyai portofolio saham ataupun obligasi dan sudah memenuhi kriteria haul serta nisabnya.

\section{DAFTAR PUSTAKA}

Al-Farisi, M. J., \& Setyawan, E. (2015). ljtihad Yusuf Qardhawi tentang Zakat Saham dan Obligasi. Al-Mustashfa Vol 3, No 2.

Aziz, M., \& Sholikah. (2015). Metode Istinbat Hukun Zakat Profrsi Perspektif Yusuf AlQardhawi dan mplikasinya terhadap Pengemangan Objek Zakat di Indonesia. Ulul Albab Volume 16, No.1.

Beik, I. S. (2019, November 7). Zakat Saham. Retrieved from BAZNAS: https://baznas.go.id/id/zakat-saham

Fatimah, L. S. (2018). Zakat Saham dan Obligasi Dalam Perspektif Hukum Islam. Yogyakarta: Universitas Islam Indonesia.

Fauziyah, R. (2010). Pemikiran Yusuf Qardhawi Mengenai Zakat Saham dn Obligasi. Jurisdictie, Jurnal Hukum dan Syariah, Vol 1, No 2, Desember.

Fielnanda, R. (2017). Zakat Saham Dalam Sistem Ekonomi Islam. Al-Tijary Jurnal Ekonomi dan Bisnis Islam Vol. 3, No. 1. 
Mubarak, I. R. (2017). Zakat Saham dan Obligasi (Studi Analisis Istinbat Hukum Yusuf AlQardawi). Makkasar: Universitas Islam Negeri. Retrieved from respositori uin alauddin: http://repositori.uin-alauddin.ac.id/4487/

Prastyo, N. S. (2019). Perandingan ijtihad yusuf Al-Qardhawi dan Wahbah Zuhaili Tentang Zakat Perusahaan. Jakarta: Universitas Islam Negeri Syarif Hidayatullah.

Ridho, M. (2018). Tinjaua Hukum Islam terhadap Zakat Saham menurut Yusuf Qardhawi dan Wahbah Az-Zuhaili. Lampung: Fakultas Syari'ah Uniersitas Islam Negeri Raden Intan.

Rukhoyah, S. (2016). Zakat Saham dan Obligasi Menurut Pandangan Yusuf Qardhawi dalam Fiqh Zakat. Palembang: Universitas Islam Negeri Raden Fatah.

Segara, T. (2019, November 7). Pasar Modal Syariah. Retrieved from OJK (Otoritas Jasa Keuangan): https://www.ojk.go.id/id/kanal/pasar-modal/Pages/Syariah.aspx

Sholeh, N. (2015). Pengembangan Hukum Islam Tentang Zakat; Memahami Konsep Zakat Obligasi dalam PEmikiran Yusuf Qardhawi. Isti'dal Jurnal Studi Hukum Islam, Vol. 2 No.1

Warsito, I. (2019, November 7). PSAK 110 : Akuntansi Sukuk. Retrieved from Ikatan Akuntan Indonesia (IAI): http://www.iaiglobal.or.id/v03/standar-akuntansikeuangan/pernyataan-sas-78-psak-110-akuntansi-sukuk

Yulia. (2016). Analisis Pengaruh Rasio Liquiditas terhadap Return Saham (Studi Pada Perusahaan Indeks LQ45 yang Terdapat di Bursa Efek Indonesia). Jurnal Khatulistiwa Informatika Vol. IV, 2, 194-195. 